\title{
ASPEK KODIKOLOGIS DAN FILOLOGIS MANUSKRIP TAFSIR PONDOK PESANTREN BUSTANUL ULUM SEDAN REMBANG
}

\author{
Nasihatul Ma'ali \\ STAI Al-Anwar Sarang-Rembang \\ maalinasichatu122@gmail.com \\ Muhammad Asif \\ Dewan Riset Daerah Kabupaten Rembang \\ asifelfarizi@gmail.com
}

\begin{abstract}
This paper examines the collection of manuscript of Tafsir Jalālayn in the Pondok Pesantren Bustanul Ulum, Sedan District, Rembang, by focusing on textological and codicological aspects. This study is crucial to do to view the characteristic form of the text contained in the ancient manuscript of tafsir Jalālayn which then led to findings on how the Quranic interpretation was studied at that time. This research is a qualitative research with a codicology and textology (philology) approach. This finding strengthens the argument that the study of tafsir, especially Jalālayn, was introduced in the Rembang area in the first half of the $19^{\text {th }}$ century, so that it can revise the findings of Van der Chijs and Van den Berg about the absence of tafsir teaching in Rembang area throughout the $19^{\text {th }}$ century. This study identifies several characteristics found in the manuscript text. First, the use of the interlinear translation (Makna Gandhul) and its Javanese codes helps the students to understand the contents of Jalālayn's Arabic interpretation. Second, the hierarchy of language contained in its translation as a form of reflection of the reader's culture in the Javanese environment. Third, the existence of marginal notes written in Arabic indicates that attempts to comment on Jalālayn had been made earlier in the area. Another interesting finding is the consistent and fairly well-established use of codes in Arabic grammatical analysis, which is an indication that Makna Gandhul had evolved in that century.
\end{abstract}

Keywords: Manuscript of Tafsir Jalālayn in Pondok Pesantren Bustanul Ulum Sedan, Codicology, characteristic of text.

\begin{abstract}
Abstrak
Tulisan ini mengkaji manuskrip tafsir Jalālayn koleksi Pondok Pesantren Bustanul Ulum Kecamatan Sedan Kabupaten Rembang dengan memfokuskan pada aspek kodikologi dan tekstologi (filologi). Kajian ini penting dilakukan untuk melihat bentuk karakteristik teks yang termuat dalam naskah kuno tafsir Jalālayn yang kemudian memunculkan temuan bagaimana tafsir dipelajari pada masa tersebut. Penelitian ini bersifat kualitatif dengan pendekatan kodikologi dan tekstologi (filologi). Temuan ini menguatkan argumen bahwa pengajian tafsir, khususnya Jalälayn sudah diperkenalkan di daerah Rembang pada paruh pertama abad ke-19, sehingga bisa merevisi temuan Van der Chijs dan Van den Berg tentang absennya pengajaran kitab tafsir di daerah Rembang sepanjang abad ke-19. Penelitian ini mengidentifikasi beberapa karakteristik yang ditemukan dalam teks manuskrip tersebut. Pertama, penggunaan Makna
\end{abstract}


Gandhul dan kode-kodenya yang berbahasa Jawa menjembatani santri untuk memahami isi kandungan tafsir Jalālayn yang berbahasa Arab. Kedua, hierarki bahasa yang tertuang dalam terjemahnya sebagai bentuk cerminan kebudayaan pembaca di lingkungan Jawa. Ketiga, adanya catatan-catatan di pinggir yang ditulis berbahasa Arab menunjukkan bahwa upaya untuk memberikan komentar terhadap Jalālayn telah dilakukan lebih dini di daerah tersebut. Temuan lain yang menarik adalah penggunaan kode-kode dalam analisis gramatika Arab secara konsisten dan cukup mapan, yang menjadi petunjuk bahwa Makna Gandhul telah berkembang di abad itu.

Kata Kunci: karakteristik teks, Kodikologi,Manuskrip Tafsir Jalālayn Pondok Pesantren Bustanul Ulum Sedan

\section{A. Pendahuluan}

Naskah kuno merupakan bagian dari benda peninggalan leluhur pada masa lalu. Naskah mampu mengungkapkan kejadian di masa lalu bagi setiap pembacanya. Naskah dapat dikatakan sebagai dokumen sejarah suatu bangsa. Dengan mengetahui sejarah maka akan terungkap identitas jati diri suatu bangsa. Para leluhur terdahulu telah mewarisi peninggalan naskah yang sangat melimpah. Keberadaannya tersebar di berbagai lembaga, seperti museum, perpustakaan maupun di tangan masyarakat. Ahli sejarah mencatat naskah temuan di Indonesia jumlahnya lebih dari 5.000 naskah, bahkan Russel Joness menyebutkan hingga 10.000 naskah. ${ }^{1}$ Dari jumlah tersebut naskah keagamaan yang paling banyak dijumpai. Dari mendominasinya temuan naskah keagamaan, naskah tafsir al-Qur'an termasuk yang paling jarang dijumpai. ${ }^{2}$ Hal tersebut berbanding terbalik dengan temuan naskah salinan mushaf alQur'an yang dijumpai hampir di setiap daerah.

Dalam sejarahnya kajian tafsir pernah mengalami kekosongan produktifitas penulisan antara kurun waktu abad ke-17 hingga ke-19 M. Pasalnya setelah Tarjumān al-Mustafìd disebut terjadi kelangkaan karangan kitab tafsir di Nusantara. Dalam kurun waktu tersebut kitab Jalālayn menjadi kitab induk bahan ajar di lembaga pendidikan Islam. Sebagaimana dikatakan oleh Karel A. Steenbrink bahwa sepanjang abad ke-19 ia hanya menemukan kitab

\footnotetext{
${ }^{1}$ Faizal Amin, "Preservasi Naskah Klasik", Jurnal Khatulistiwa, vol. 1. no. 1, (2011), hlm. 90. (https://doi.org/10.24260/khatulistiwa.v1i1.184)

${ }^{2}$ Jajang Rohmana, "Empat Manuskrip Al-Qur'an di Subang Jawa Barat", Wawasan: Jurnal Ilmiah Agama dan Sosial Budaya, vol. 3, no. 1, (2018), hlm. 1. (https://doi.org/10.15575/jw.v3i1.1964)
} 

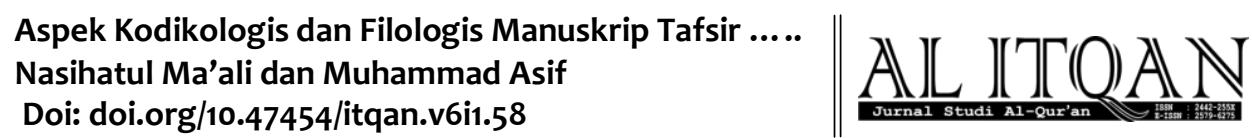

Jalālayn sebagai kitab pegangan dalam pembelajaran bidang tafsir. ${ }^{3}$ Sangat jarang kitab lain apalagi tafsir lokal yang digunakan sebagai bahan ajar.

Dengan alasan tersebut seharusnya kegiatan penyalinan kitab Jalālayn banyak dilakukan. Beberapa titik lokasi menunjukkan penemuan naskah salinan Jalālayn antara lain di Sumatra Barat milik Ahmar Zen, ${ }^{4}$ di Lasem milik Mbah Topo, ${ }^{5}$ di Sedan milik Kiai Syarbini, di Tuban milik KH. Nur Hisyam, ${ }^{6}$ di Cirebon milik Haji Muhammad Hasan Basri dan mungkin masih banyak lagi yang masih disimpan di masyarakat. Namun tetap saja, jumlah tersebut masih sangatlah kecil jika dibandingkan dengan temuan naskah keagamaan lainnya.

Penelitian mengenai naskah kuno berupa salinan seperti Jalālayn seharusnya tidak luput dari perhatian para peneliti. Bagaimanapun naskah salinan merupakan bagian dari naskah kuno sebagai saksi sejarah perkembangan keilmuwan di Nusantara. ${ }^{7}$ Salinan Jalālayn dapat menjadi alternatif dalam membaca perkembangan tafsir selama kekosongan karya tafsir di Nusantara, terutama di daerah Rembang. Dalam catatan Van der Chijs berdasarkan hasil survey terhadap pendidikan pribumi, khususnya kitab-kitab berbahasa Arab yang lazim digunakan di daerah Rembang pada tahun 1864 disebutkan bahwa tidak terdapat satupun kitab tafsir yang dipelajari di sana. Dari hasil pendataannya hanya tercatat Kitab Alif-ba-Ta, Turutan, Fatihah, Yasin, al-Qur'an, Kitab Aliflam, Kitab AsmoroKondi, Kitab Nahwu, Kitab Sorof, Kitab Amil dan Kitab Jurumiyah yang dipelajari di Rembang pada tahun $1864 .{ }^{8}$

\footnotetext{
${ }^{3}$ Karel A Steenbrink, Beberapa Aspek Tentang Islam di Indonesia Abad ke-19, (Jakarta: Bulan Bintang, 1980), hlm. 60.

${ }^{4}$ Kemenag, Naskah Tafsir Jalalyn di Sumbar, Lektur Kemenag, dalam: https://lektur.kemenag.go.id/manuskrip/web/koleksi-detail/lkk-sumbar2016-ap03.html\#ad-image-0, (diakses pada 14 Oktober 2019).

${ }^{5}$ Ahmad Sholeh, 'Sejarah Manuskrip Kitab Tafsir Jalalin di Perpustakaan Masjid Jami’ Lasem Rembang Jawa Tengah", dalam: https://www.academia.edu/38664952/Sejarah_Manuskrip_Kitab_Tafsir_Jalalain_di_perpustakan_Masjid_Jami_ Lasem_Rembang_Jawa_Tengah, (diakses pada 14 Oktober 2019).

${ }^{6}$ Mir'atul Af'idah, "The Caracteristic of Jalālain Exegesis Manuscript From Mandirejo: Philological Study", (Skripsi di STAI Al-Anwar Rembang), 2018.

${ }^{7}$ Nabilah Lubis, Naskah, Teks dan Metode Penelitian Filologi, (Jakarta: Yayasan Media Alo Indonesia, 2007), hlm. 30.

${ }^{8}$ J. A. Van der Chijs, "Bijdragen Tot de Geschiedenis Van Het Inlandsch Onderwijs In Nederlandsch-Indië", Tijdschrift Voor Indische Taal-Land-en Volkenkunde Uitgegeven Door Het Bataviaasch Genootschap van Kunsten en Wetenschappen, vol. 14, no. 5, (1864), hlm. 217.
} 
Pernyataan tersebut sejalan dengan hasil pendataan Van den Berg pada akhir abad yang sama (1886) menyebutkan minimya kajian tafsir di sepanjang pantai utara pulau Jawa. ${ }^{9}$

Belakangan ini penulis menemukan manuskrip salinan kitab tafsir Jalālayn di Pondok Pesantren Bustanul Ulum Sedan, Rembang Jawa Tengah. Naskah tersebut merupakan koleksi pribadi Pondok Pesantren Bustanul Ulum, Sedan, Rembang yang saat ini di bawah asuhan Kiai Sirojjudin Azizi. Maka penelitian terhadap naskah salinan tersebut dengan analisis filologi dianggap penting untuk mengungkap informasi yang ada di dalamnya.

Penelitian ini juga berusaha mendeskripsikan bentuk fisik naskah dari aspek kodikologi dan menganalisis karakteristik teks dari segi tekstologi. Penelitian dilakukan dengan metode kualitatif yang bersifat deskriptif analisis dengan menggunakan teori kodikologi sebagai alat analisis deskripsi naskah dan teori filologi sebagai analisis teks terjemah dan syarh naskah. Oman Fathurahman mengatakan kedua aspek (kodikologi dan filologi) merupakan dua komponen yang saling berkaitan erat dalam membangun penelitian naskah kuno. Namun keduannya merupakan bagian yang berbeda. Jika filologi hanya dapat menyentuh salah satu aspek yang terkandung dalam naskah ${ }^{10}$ yakni teksnya, maka kodikologi hanya menyentuh bagian di luar teks naskah, seperti bentuk fisik naskah, sejarah naskah dan asal usul naskah serta penggunaan naskah ${ }^{11}$. Hasil dari penelitian ini diharapkan dapat memberi kontribusi terhadap daftar kajian naskah kuno di bidang tafsir.

\section{B. Deskripsi Naskah}

Naskah yang dikaji dalam penelitian ini merupakan salinan kitab tafsir Jalālayn karya Jalaluddin al-Mahalli dan al-Suyuti. Tidak ditemukan judul khusus yang tertulis di dalam naskah. Kandungan naskah merupakan bagian awal matan kitab tafsir Jalālayn yang dimulai dari surah al-Baqarah: 19 hingga surah al-Ra'du yang memuat 13 juz. Penyalin naskah tidak diketahui. Naskah merupakan salah satu koleksi Pondok Pesantren Bustanul Ulum Sedan, Rembang yang saat ini berada di bawah asuhan Kiai Sirojjudin Azizi. Oleh karena hal tersebut penulis menyebutnya dengan naskah tafsir Jalälayn Pondok Pesantren Bustanul

\footnotetext{
${ }^{9}$ L.W.C. Van den Berg, Het Mohammedaansche Godsdienstonderwijs of Java en Madoera En Daarbij Gebruikte Arabische Boeken, Tijdschrift Voor Indische Taal-Land-en Volkenkunde Volkenkunde Uitgegeven door Het Bataviaasch Genootschap van Kunsten En Wetenschappen, vol. 31, (1886), hlm. 523.

${ }^{10}$ Oman Fathurahman, Filologi Indonesia: Teori dan Metode, (Jakarta: Prenadamedia Group, 2015), hlm. 109.

${ }^{11}$ Sri Wulan Rudjiati Mulyadi, Kodikologi Melayu di Indonesia, (Depok: Lembar Sastra Fakultas Sastra Univrsitas Indonesia, 1994), hlm. 3.
} 

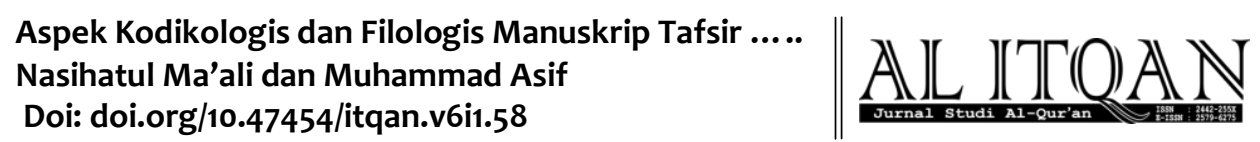

Ulum Sedan untuk mempermudah penyebutan dan membedakan dari naskah-naskah tafsir Jalālayn lainnya.

Secara umum keadaan fisik naskah terbilang rapuh. Sampul hanya dijumpai di bagian belakang yang terbuat dari karton dilapisi kain hitam bercorak bunga. Kondisi kertas mulai melapuk sehingga beberapa bagian tidak memungkinkan untuk diakses. Bagian atas yang mulai rontok dan rapuh, namun bagian teks masih dapat terbaca jelas. Penjilidan naskah sebagian telah lepas terutama bagian depan sehingga beberapa lembar telah rusak dan hilang. Naskah terdiri dari 1 jilid setebal $3 \mathrm{~cm}$ dengan 10 kurasan yang terhitung utuh.

Naskah memuat 300 halaman dengan 19 baris di setiap halamannya. Ukuran naskah 32 x 19,5 cm dan teks naskah berukuran 21 x 11,4 cm ditulis dengan bahasa Arab untuk bagian matan dan pegon bahasa Jawa untuk terjemah (makna gandhul). Diksi yang digunakan dalam terjemah naskah mengindikasikan Bahasa Jawa dialek pantai utara Jawa atau disebut dialek Muria, yaitu dialek wilayah pesisir utara bagian Timur Jawa Tengah. Seperti diksi dlamakan $^{12}$ yang berarti telapak kaki, yang familiar untuk penduduk daerah pesisir utara atau dialek Muria. ${ }^{13}$ Selain itu dijumpai pula diksi yang lebih khusus wilayah Rembang seperti kata bento ${ }^{14}$ yang berarti bodoh,dan cemer $^{15}$ yang berarti lumpur (kotor). Keduanya lebih sering digunakan di daerah Rembang. ${ }^{16}$ Dari diksi yang digunakan tersebut menunjukkan besar kemungkinan naskah kajian berasal dari daerah dijumpainnya naskah yaitu daerah Rembang. Terlebih di daerah tersebut sudah ada tradisi penulisan keagamaan yang dibuktikan dengan temuan beberapa naskah kuno keagamaan. Penulis menjumpai 3 naskah lainnya di tempat ditemukannya naskah kajian yaitu sebuah naskah tafsir Jalālayn juz akhir, sebuah naskah ushuluddin dan sebuah naskah dalam bidang tauhid. Penelusuran yang dilakukan oleh Islah Gusmian dkk., di Rembang pada 2009 juga berhasil mengidentifikasikan beberapa manuskrip keagamaan di Rembang, di antaranya Qașd al-Amali, Bahjah al-Ulum, salinan tafsir Jalālayn dan beberapa naskah keagamaan yang belum diidentifikasi judulnya. ${ }^{17}$

Dalam naskah ini jarak antar baris $1 \mathrm{~cm}$, sebagai ruang untuk terjemah makna gandhul. Jarak pias kanan $2 \mathrm{~cm}$ pias kiri $7 \mathrm{~cm}$, pias atas $6 \mathrm{~cm}$ dan bawah $6 \mathrm{~cm}$. Tinta yang

\footnotetext{
${ }^{12}$ MS. Tafsir Jalālayn Pondok Pesantren Bustanul Ulum Sedan, hlm. 43.

${ }^{13}$ Soedjarwo dkk, Geografi Dialek Bahasa Jawa Kabupaten Rembang, (Jakarta: Pusat Pembinaan dan Pengembangan Bahasa Departemen Pendidikan dan Kebudayaan, 1987), hlm. 205.

${ }^{14}$ MS. Tafsir Jalālayn Pondok Pesantren Bustanul Ulum Sedan, hlm.1.

${ }^{15}$ Ibid., hlm. 27.

${ }^{16}$ Soedjarwo dkk., Geografi Dialek Bahasa Jawa Kabupaten Rembang, hlm. 51-64.

${ }^{17}$ Versi digital dari naskah-naskah tersebut disimpan di Pusat Studi Naskah IAIN Surakarta. Naskah dideskripsikan oleh Muhammad Asif dan Cholid Abdullah.
} 
digunakan untuk menulis naskah berwarna merah dan hitam. Tinta merah untuk ayat alQur'an, tanda ruku' dan tanda pergantian juz. Sedangkan tinta hitam untuk matan tafsir alQur'an, terjemah makna gandhul dan syarah tafsir. Kondisi tinta pada naskah di beberapa bagian telah luntur menyebabkan teks tidak terbaca.

Alas naskah berupa kertas Eropa dengan ditemukannya watermark (cap kertas) bertuliskan "Propatria" bergambar seorang wanita duduk dengan membawa tongkat bersama seekor singa yang membawa pedang di dalam lingkar pagar kayu dan singa yang membawa pedang di dalam lingkar pagar kayu. Dijumpai pula countermark (cap kertas tandingan) bertuliskan "M V LIER \& ZooN" dan "BLAUW \& BRIEL".

Ciri-ciri demikian merupakan jenis watermark "Pro Patria"18 yang diproduksi oleh perusahaan milik B. Cramer asal Belanda pada tahun $1711 .{ }^{19}$ Sedangkan countermark MV LIER \& Zoon merupakan tanda air pada kertas produksi Belanda tahun 1830 oleh pabrik The Hague. ${ }^{20}$ Untuk kertas dengan countermark BLAUW \& BRIEL diproduksi pada tahun 17241825 oleh pabrik wilayah Wormerveer dan Zaandyck, Belanda. ${ }^{21}$

Dari data tersebut dapat diperkirakan bahwa naskah tafsir Jalālayn Pondok Pesantren Bustanul Ulum Sedan ditulis sekitar pertengahan abad ke-19 M. berdasarkan perhitungan tahun produksi kertas yang paling muda, yaitu kertas ber-countermark MV LIER \& Zoon (1830 M.). Russel Jones sebagaimana dikutip Rujiati mengatakan bahwa naskah Melayu ditulis pada kertas yang umurnya kurang dari delapan tahun. ${ }^{22}$ Dari sini bisa ditarik bahwa penulisan naskah tafsir Jalālayn Pondok Pesantren Bustanul Ulum Sedan sekitar beberapa tahun (kurang lebih delapan tahun) setelah tahun produksi kertas, yaitu sekitar $1840 \mathrm{M}$. Hal tersebut dapat dibenarkan karena di Nusantara sepanjang abad ke-19 M. kegiatan penulisan dan penyalinan naskah berkembang begitu pesat. ${ }^{23}$ Naskah tafsir Jalālayn Pondok Pesanten Bustanul Ulum Sedan sebagai salah satu bukti pesatnya kegiatan penyalinan pada masa tersebut. Temuan ini sekaligus menunjukkan bahwa pengajian tafsir Jalālayn di daerah Rembang telah diperkenalkan pada abad tersebut. Temuan ini bertolak belakang dengan hasil

\footnotetext{
${ }^{18}$ Fakhriati, "The Use of Paper in the Acehnese Islamic Manuscripts and Its Historical Context", Hiritage of Nusantara International Journal of Religious Literature Heritage, vol.2, no. 1, (2013), hlm. 60.

${ }^{19}$ W.A. Churchill, Watermarks In Paper In Holland, Englad, France etc: In The XVII Centuries and Their Interconnection, (Amsterdam: Menno Hertzberger \& Co, 1965), hlm. 47.

${ }^{20}$ Ibid., hlm. 16.

${ }^{21}$ Ibid., hlm. 13.

${ }^{22}$ Sri Wulan Rujiati Mulyadi, Kodikologi Melayu di Indonesia, hlm. 66.

${ }^{23}$ Ibid., hlm. 66.
} 
Aspek Kodikologis dan Filologis Manuskrip Tafsir ..... Nasihatul Ma'ali dan Muhammad Asif

Doi: doi.org/10.47454/itqan.v6i1.58

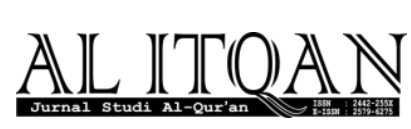

survei sarjana Belanda Van der Chijs ${ }^{24}$ dan Van den Berg ${ }^{25}$ yang mengatakan bahwa di daerah Rembang tak ada satupun kajian kitab tafsir yang dipelajari pada abad ke-19.

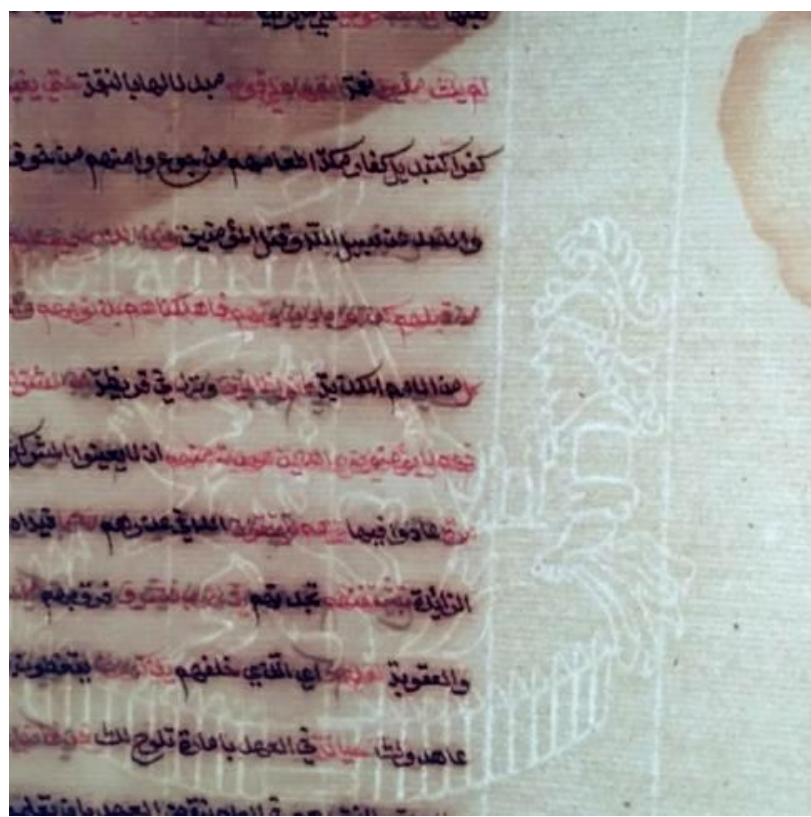

Gambar 1 watermark jenis Pro Patria pada alas naskah.

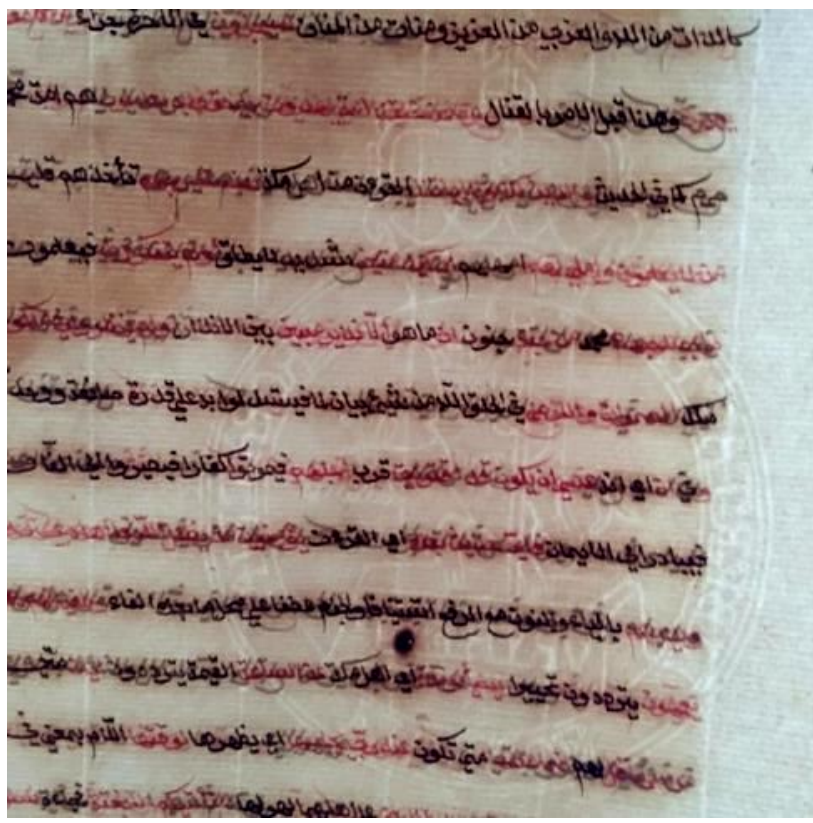

Gambar 2 Watermark lain pada alas naskah.

\footnotetext{
${ }^{24}$ J. A. Van der Chijs, "Bijdragen Tot de Geschiedenis Van Het Inlandsch Onderwijs In Nederlandsch-Indië", Tijdschrift Voor Indische Taal-Land-en Volkenkunde Uitgegeven Door Het Bataviaasch Genootschap van Kunsten en Wetenschappen, vol. 14, no. 5, (1864), hlm. 217.

${ }^{25}$ L. W.C. Van den Berg, "Het Mohammedaansche Godsdienstonderwijs of Java en Madoera en Daarbij Gebruikte Arabische Boeken", Tijdschrift Voor Indische Taal-Land-en Volkenkunde Uitgegeven Door Het Bataviaasch Genootschap van Kunsten en Wetenschappen, vol. 31, (1886), hlm. 523.
} 


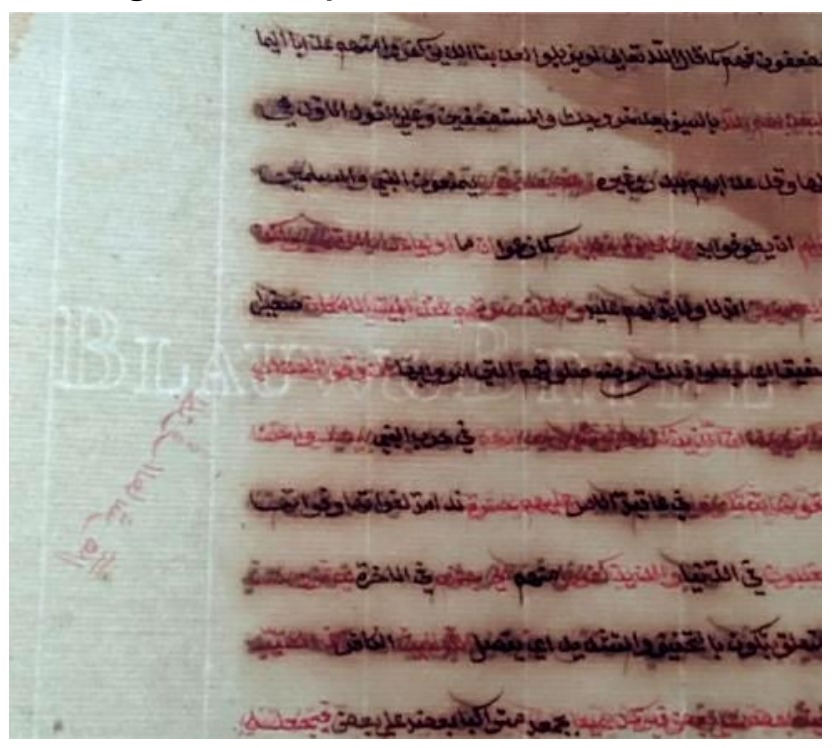

Gambar 3 Countermark Blauw \& Briel pada alas naskah.



Gambar 4 Countermark MV Lier \& ZooN pada alas naskah.

Dalam naskah juga terdapat kata alihan (cacthword) di verso akhir pergantian juz. Tidak terdapat nomor halaman. Terdapat tanda awal juz di setiap pergantian juz pada bagian pias samping naskah kanan maupun kiri sesuai letak pergantian juz. Terdapat tanda ruku' seperti halnya pada mushaf al-Qur'an.

Naskah dipercantik dengan dua iluminasi yang berada di awal juz dua sebagai simbol pergantian juz. Iluminasi bermotif bunga dan daun memanjang di pias kanan dan kiri awal juz 2. Pada bagian tengahnya terdapat lingkaran berwarna biru dan kuning keemasan yang diisi tulisan al-juz'u dan al-thānī. 


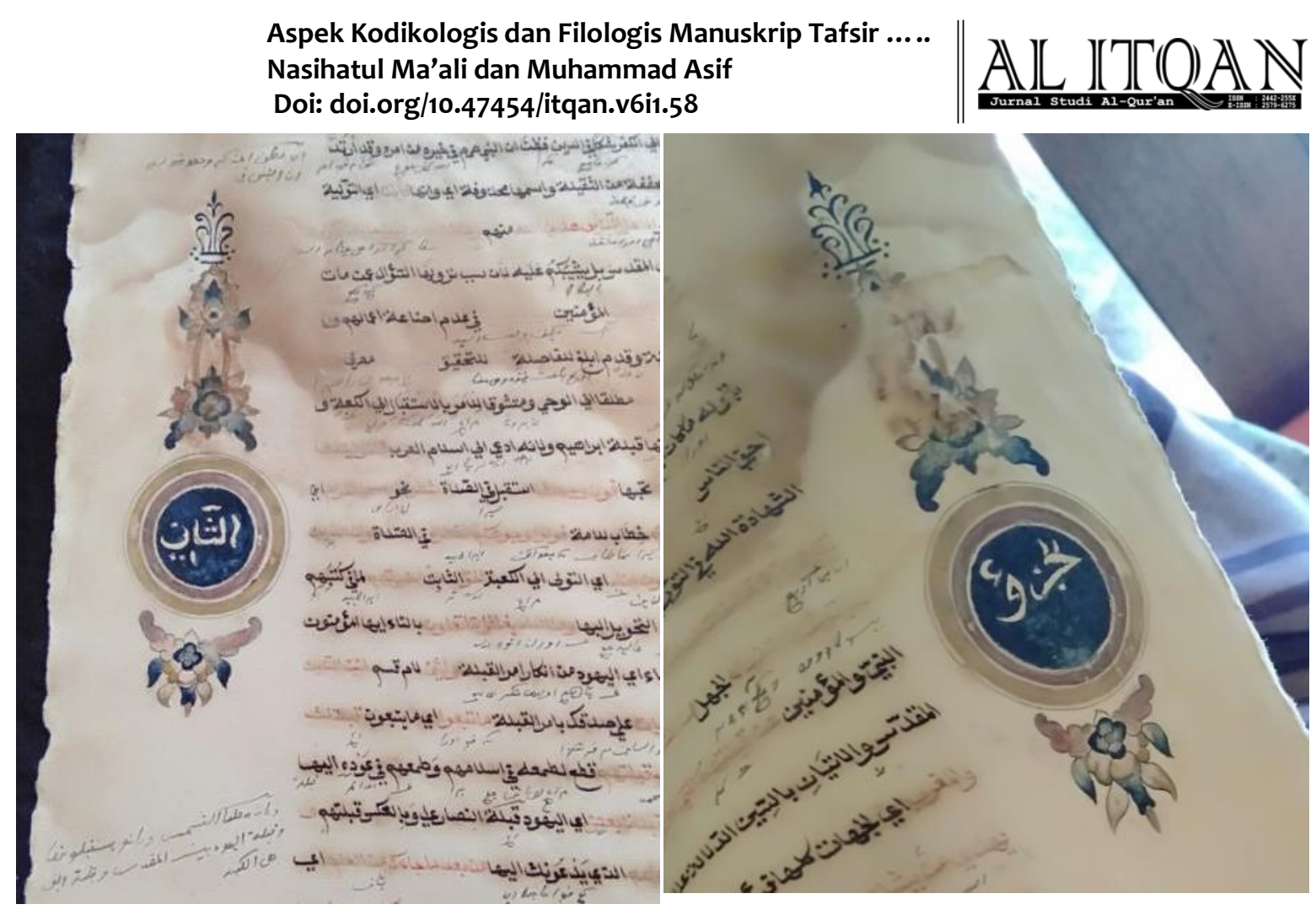

Gambar 5 Iluminasi pada pergantian juz 2

Pada bagian akhir naskah ditemukan sebuah pesan berisi keterangan fungsi naskah, tujuan penyalinan dan pesan untuk pembaca naskah tersebut. Isi pesannya tidak terbaca lengkap karena bagian naskah yang telah melapuk dan terpotong. Berikut transkip dari pesan pada bagian akhir naskah:

“Sudara2, seng ningali, supados kula nyuwun se'baniki tulisan (selanjutnya teks memudar dan tidak terbaca), sekolah, sadjake tulisan kumang, nyuwun ngapura, (diakhiri dengan tanda tangan penulis pesan)

Saudara-saudara, yang melihat (membaca), saya mohon, sebab tulisan ini, sekolah, sesungguhnya tadi adalah tulisan saya, mohon maaf

Dari pesan tersebut diperkirakan bahwa naskah digunakan untuk tujuan mengaji bandongan (mengaji dengan memaknai kitab yang salah satu metode dalam pesantren). ${ }^{26} \mathrm{Hal}$ lain yang memperkuat argumen tersebut adalah jarak antar baris yang dibuat renggang sebagai ruang khusus untuk menulis makna gandhul (terjemah). Terlihat goresan tinta yang digunakan untuk menulis pesan jauh lebih muda dibandingkan dengan goresan tinta yang ada dalam naskah. Menurut informasi dari Kiai Sirojjudin Azizi, pemilik naskah saat ini, menyebutkan tidak tahu persis asal mula dari naskah yang berada di dalam almari milik ayahnya.Ia mengatakan:

\footnotetext{
${ }^{26}$ Zamakhsyari Dhofier, Tradisi Pesantren: Studi Pandangan Hidup Kyai dan Visinya Mengenai Masa Depan Indonesia, (Jakarta: LP3ES, 1982), hlm. 51.
} 
"Keadaan naskah sudah lapuk dan tak memungkinkan untuk digunakan apalagi untuk pengajian rutinan pasti akan memperburuk keadaan naskah. Saya sendiri tidak pernah melihat ayah saya menggunakan kitab (naskah) tersebut. Selama ini hanya disimpan dalam almari sebagai benda peninggalan."27

Keterangan pemilik naskah tersebut memberi informasi bahwa naskah telah lama disimpan dan tidak pernah digunakan untuk mengaji karena keadaannya sudah tidak memungkinkan untuk digunakan. Selama masa ayahnya masih hidup, naskah tersebut sudah tidak difungsikan sebagaimana masa naskah tersebut ditulis.

\section{Karakteristik Teks Naskah Tafsir Jalälayn Pondok Pesantren Bustanul Ulum Sedan}

Berikut karakteristik teks naskah tafsir Jalālayn Pondok Pesantren Bustanul Ulum Sedan yang difokuskan pada aspek terjemah dan syarahnya. Penelitian ini membatasi kajianpada QS. al-Baqarah yang ada pada naskah.

\section{Penggunaan Makna Gandhul Pertengahan abad ke-19}

Makna gandhul atau makna $u t a w i^{28}$ terkadang disebut terjemah jenggotan ${ }^{29}$ memiliki definisi teknik penerjemahan teks berbahasa Arab kata per kata dengan cara menuliskan terjemahnya tepat di bawah kata yang bersangkutan menggunakan huruf Arab. ${ }^{30}$ Kaitannya dengan naskah, tampaknya makna gandhul sengaja dipilih sebagai media terjemah karena bahasa Jawa dianggap lebih dekat dan lebih mudah dipahami bagi pembaca dan pelajar pada masa tersebut. Sebagaimana disebutkan dalam analisis umur naskah yang menunjukkan tahun1840 M. Dimana masyarakat di Nusantara lebih akrab dengan bahasa daerah masingmasing. Ketika sumpah pemuda ditetapkan pada 28 Oktober 1928 M. barulah bahasa Indonesia mulai dikenal dan ditetapkan sebagai bahasa persatuan. ${ }^{31}$ Mungkin karena sebab itu penerjemah naskah memilih teknik makna gandhul yang berbahasa Jawa sebagai teknik terjemah.

\footnotetext{
${ }^{27}$ Wawancara dengan Kiai Sirojjudin, (Sedan, Rembang, 27 Februari 2020).

${ }^{28}$ Masrukhi, "Penerjemahan Arab-Jawa Tradisi Pesantren Pada Karya Kitab-Kitab Klasik: Analisis Fungsi", Sasdaya Gadjah Mada Journal of Humanities, vol. 2, no. 1, (2017), hlm. 284. (https://doi.org/10.22146/sasdayajournal.31744)

${ }^{29}$ Martin van Bruiness, "Kitab Kuning: Books In Arabic Script Used In The Pesantren Milleu”, Bijdragen, (1990), hlm. 235.

${ }^{30}$ Muhammad Asif, "Tafsir dan Tradisi Pesantren: Karakteristik Tafsir al-Ibīz Karya Bisri Mustofa”, Șuḥuf Jurnal Pengkajian al-Qur'an dan Budaya, vol. 9, no. 2, (2016), hlm. 252. (https://doi.org/10.22548/shf.v9i2.154)

${ }^{31}$ Sudaryanto, "Tiga Fase Perkembangan Bahasa Indonesia 1928-2019", Jurnal Pendidikan dan Sastra Indonesia, vol.2, no. 1, (2018), hlm. 7. (https://doi.org/10.21009/AKSIS.020101)
} 


\section{Aspek Kodikologis dan Filologis Manuskrip Tafsir ..... Nasihatul Ma'ali dan Muhammad Asif \\ Doi: doi.org/10.47454/itqan.v6i1.58}

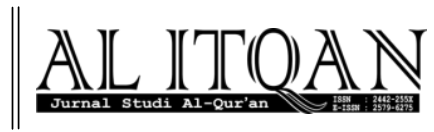

Makna gandhul yang dimaksud di sini bukan hanya sekedar penerjemahan berbentuk miring di bawah kata yang bersangkutan, namun telah menggunakan kode-kode seperti utawi yang menunjukkan posisi mubtada' (subjek), sebagai analisis gramatika bahasa Arab. Selain membantu pemahaman mengenai maknanya, pembaca dapat sekaligus belajar bahasa Arab dengan penerapakan kode-kode tersebut.

Berikut beberapa kode-kode yang digunakan dalam terjemah makna gandhul naskah tafsir Jalālayn Pondok Pesantren Bustanul Ulum Sedan. Pertama, diksi utawi sebagai terjemah setiap lafadz yang menempati posisi mubtada'. Kode tersebut telah konsisten digunakan pada terjemah yang menempati posisi sebagai mubtada'. Kedua, diksi sopo dan opo menunjukkan posisi sebagai fä'il (pelaku), penggunaannya hanya konsisten pada terjemah yang matan tafsirnya disebutkan secara lafdzi saja. Ketiga, diksi ing menunjukkan posisi lafaz sebagai maf'ūl bih (objek) yang telah konsisten digunakan pada terjemah yang lafaz yang disebutkan atau pun yang tidak disebutkan.

Keempat, diksi kang dan sing menunujukkan posisi sebagai na'at (sifat). Kode ini cukup konsisten digunakan pada setiap terjemah lafadz yang menempati posisi na'at. Kelima, diksi hăale menunjukkan kode terjemah pada lafadz yang menempati posisi sebagai hăa l. Kemudian diksi bayāne dan nyatane merupakan kode pada terjemah lafadz yang kemasukan huruf min bayān al-jinsi. Keduanya telah digunakan dengan konsisten secara bergantian. Keenam, diksi drapon merupakan kode pada terjemah lafadz yang kemasukan lam kay. Kode drapon juga konsisten dalam penggunaannya, hampir dijumpai pada setiap lafadz yang kemasukan lam kay.

Ketujuh, diksi ingdalem merupakan kode pada terjemah lafadz yang menempati posisi sebagai zaraf (keterangan tempat maupun waktu) dan setiap lafadz berfaidah zarfiyah. Kode ingdalem telah konsisten digunakan dalam naskah. Kedelapan, diksi opone merupakan kode pada terjemah pada lafadz yang menempati posisi sebagai tamyiz. Penggunaa diksi opone masih jarang digunakan dalam naskah. Berdasarkan pengamatan penulis, kode opone hanya digunakan sebanyak dua kali sepanjang QS. al-Baqarah dan banyak posisi tamyiz yang luput dari penerjemahan diksi opone. Hal tersebut menunjukkan diksi opone baru dipraktikan dalam teknik Makna Gandhul sehingga penggunaannya masih sangat minim.

Contoh bentuk Makna Gandhul yang ada dalam naskah Tafsir Jalālayn Pondok Pesantren Bustanul Ulum Sedan. 




liyatmainna/drapon anteng, qalbi/opo ati ingsung ${ }^{32}$

agar hatiku tenang (mantap) ${ }^{33}$

Makna Gandhul di atas telah menggunakan kode berupa drapon dan opo. Lafadz liyațainna diterjemahkan dengan tambahan kode drapon karena kemasukan lam kay. Untuk lafadz selanjutnya yaitu lafadz qolbī diterjemahkan dengan tambahan kode opo karena posisinya sebagai fā'il (subyek) dari lafadz yațainna.

Jika dibandingkan dengan kode Makna Gandhul yang kita kenal pada saat ini, kode $i k u$ (mewakili khabar) sama sekali tidak dijumpai dalam naskah kajian. Berarti kode iku masih belum digunakan pada masa teks tersebut ditulis. Hal ini cukup mengherankan karena kode iku biasanya dipasangkan dengan kode utawi (mubtada') yang dalam naskah telah digunakan secara konsisten.

Sebenarnya penggunaan kode-kode demikian dianggap suatu kewajaran sebagaimana pada kitab-kitab ber-Makna Gandhul lainnya. Persoalan muncul ketika Makna Gandhul demikian hadir pada dua abad silam. Dan kehadiran Makna Gandhul demikian dianggap lahir cukup dini pada masa tersebut. Sejauh ini Makna Gandhul diperkirakan muncul pada abad ke19 M. namun itupun belum dalam bentuk yang kompleks seperti saat ini.

Penggunaan Makna Gandhul dalam naskah Tafsir Jalālayn Pondok Pesantren Bustanul Ulum Sedan tampaknya sudah ditetapkan sejak matan tafsir ditulis. Terlihat dengan jarak antar baris yang cukup lebar yang sengaja dibuat demikian sebagai ruang penulisan terjemah Makna Gandhul. Hal tersebut menunjukkan Makna Gandhul telah berkembang ketika naskah tersebut ditulis.

Sebagaimana dikatakan oleh para peneliti Makna Gandhul,bahwa hasil akulturasi budaya Jawa dan Islam tersebut berakar dari munculnya aksara Pegon. Pudjiastuti menyebutkan bahwa Pegon muncul dari rahim pesantren tradisional yang merupakan pusat keilmuwan agama Islam di Nusantara. Para santri yang akrab dengan tulisan Arab memodifikasi bentuknya sebagai sarana penulisan teks-teks berbahasa Jawa. Kemudian dari

\footnotetext{
${ }^{32}$ MS. Tafsir Jalālayn Pondok Pesantren Bustanul Ulum Sedan, hlm. 47.

${ }^{33}$ Al-Quddus: Al-Qur'an dan Terjemahnya, (Kudus: CV. Mubarokatan Thoyyobah, tth), hlm.43.
} 


\section{Aspek Kodikologis dan Filologis Manuskrip Tafsir ..... Nasihatul Ma'ali dan Muhammad Asif \\ Doi: doi.org/10.47454/itqan.v6i1.58}

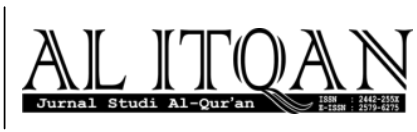

situlah aksara Pegon lahir. ${ }^{34}$ Pingued sebagaimana dikutip Martin van Bruinessen menyebutkan pesantren merupakan jenis pusat Islam kedua setelah masjid yang muncul pada abad ke- $16^{35}$ sehingga diperkirakan Pegon juga muncul pada masa tersebut.

Tampaknya Makna Gandhul muncul pada masa jauh setelah pegon. Sejauh ini belum ada penelitian yang membahas mengenai akar sejarah Makna Gandhul secara mendalam. Dugaan awal naskah temuan paling awal yang menggunkan Makna Gandhul adalah karyakarya Kiai Soleh Darat yang ditulis pada akhir abad ke-19. ${ }^{36}$

Argumentasi tersebut bertolak belakang dengan hadirnya Makna Gandhul dalam naskah tafsir ini yang lahir sekitar tahun 1840 M. berdasarkan analisis kodikologis pada alas naskah. Keberadaan naskah Tafsir Jalālayn Pondok Pesantren Bustanul Ulum Sedan telah menggunakan Makna Gandhul dengan kode-kodenya yang sudah cukup mapan menunjukkan bahwa tafsir telah dipelajari sejak pertengahan abad ke-19 serta analisis gramatika telah diterapkan untuk memahami tafsir dan al-Qur'an.

\section{Bahasa Terjemah yang Berhierarki}

Terjemah yang digunakan naskah selain memiliki bentuk aksara yang unik juga ditemukan di dalamnya memuat bentuk tingkatan bahasa. Tingkatan tersebut terbentuk berdasarkan bahasa pengantar yang digunakan, yaitu bahasa Jawa. Adat Jawa dengan segala kebudayaannya termasuk bahasanya memiliki etika dalam berkomunikasi yang kemudian diterapkan dalam segala situasi termasuk ketika menerjemahkan suatu naskah. Tingkatan bahasa tersebut dikenal dengan hierarki bahasa. Hierarki bahasa, dalam bahasa Jawa memiliki tingkatan (unggah-ungguh) di mana tingkat kehalusan diksi yang digunakan bergantung pada pihak-pihak yang berdialog. ${ }^{37}$

Ada tiga pihak yang terlibat dalam hubungan komunikasi tersebut yaitu penutur, lawan tutur dan pihak lain yang menjadi objek tuturan. Kemudian dalam konsep unggahungguh tersebut akan memicu terjadinya perbedaan bentuk tuturan dalam bahasa yang

\footnotetext{
${ }^{34}$ Titik Pudjiastuti, "Tulisan Pegon Wujud Identitas Islam-Jawa: Tinjauan atas Bentuk dan Fungsinya”, Șuhuf Jurnal Pengkajian al-Qur'an dan Budaya, vol. 2, no. 2, (2009), hlm. 272. (https://doi.org/10.22548/shf.v2i2.92)

${ }^{35}$ Martin van Bruinessen, Kitab Kuning Pesantren dan Tarekat, (Bandung: Mizan, 1995), hlm. 24.

${ }^{36}$ Muhammad Asif, "Tafsir dan Tradisi Pesantren: Karakteristik Tafsir al-Ibīz Karya Bisri Mustofa", hlm. 253. (https://doi.org/10.22548/shf.v9i2.154)

${ }^{37}$ Ridhoul Wahidi, "Hierarki Bahasa dalam Tafsir Al-Ibrīz li Ma'rifah Tafsīr al-Qur'an al- 'Azīz Karya KH. Bisri Musthofa”, Șụuf Jurnal Pengkajian al-Qur'an dan Budaya, vol. 8, no. 1, (2015), hlm. 148. (https://doi.org/10.22548/shf.v8i1.18)
} 
disesuaikan pada status masing-masing. ${ }^{38}$ Secara umum hal tersebut disebabkan oleh faktorfaktor kedudukan seseorang dalam masyarakat berdasarkan kebangsawanan, umur dan kewibawaaan. ${ }^{39}$ Berikut bentuk hierarki bahasa yang terdapat dalam naskah Tafsir Jalālayn Pondok Pesantren Bustanul Ulum Sedan.

Pertama, tingkatan bahasa dalam naskah ditemukan pada terjemah dialog dua pihak yang memiliki kedudukan berbeda. Tuturan satu pihak akan diterjemahkan dengan bahasa yang sangat halus sebagai bentuk penghormatan terhadap lawan tuturnya yang berkedudukan tinggi. Sedangkan pihak lawannya akan diterjemahkan dengan bahasa yang kasar sebagai indikasi dialog terhadap lawan tutur yang berkedudukan lebih rendah darinya. Sebagaimana dalam terjemah QS. Al-Baqarah: 247.

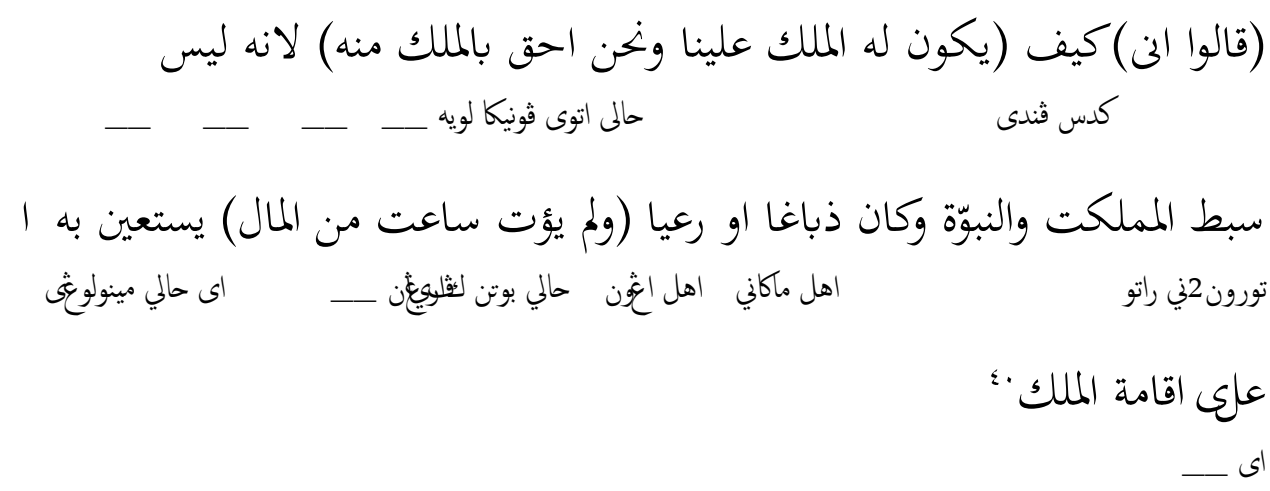

Qalū anna kados pundi, yakunu lahu al-mulku 'alayna, wananḥnu aḥaqqa hale utawi puniko luwih hak, bi al-mulki minhu, li annahu laysa sibți mamlukati ora turun2ne ratu, wa al-nubuwah (lan nabi) wa kāna, dabbaghon ahli makani, aw ra'iyyan ahli angon, wa lam yu'ta sā'atan min al-māl hale boten keparingan mal (harta), yasta'īnu ay (tegese) hale minulungi, biha , 'alā iqāmati almulki. ${ }^{41}$

(Kata Nabi mereka kepada mereka, "Sesungguhnya Allah telah mengangkat Talut bagi kamu sebagai raja." Jawab mereka,"Bagaimana) artinya betapa (ia akan menjadi raja kami, padahal kami lebih berhak terhadap kerajaan ini daripadanya) ia bukan dari keturunan raja-raja atau bangsawan dan tidak pula dari keturunan nabi-nabi. Bahkan ia hanya tukang samak atau gembala (sedangkan ia pun tidak diberi kekayaan yang mencukupi) yakni yang amat diperlukan untuk membina atau mendirikan suatu kerajaan.

\footnotetext{
${ }^{38}$ Muhammad Asif, "Tafsir dan Tradisi Pesantren: Karakteristik Tafsir Al-Ibrīz Karya Bisri Mustofa”, hlm. 257. (https://doi.org/10.22548/shf.v9i2.154)

${ }^{39}$ Imam Muhsin, Al-Qur'an dan Budaya dalam Tafsir al-Huda Karya Bakri Syahid, (Yogyakarta: eLSAQ, 2013), hlm. 123.

${ }^{40}$ MS. Tafsir Jalālayn Pondok Pesantren Bustanul Ulum Sedan, hlm. 42.

${ }^{41}$ Ibid., hlm. 42.

${ }^{42}$ Jalaluddin al-Mahalli dan Jalaluddin al-Suyuti, Tafsir Jalalain, terj. Bahrun Abu Bakar dkk, (Bandung: Sinar Baru Algensindo, 2019), hlm. 135.
} 

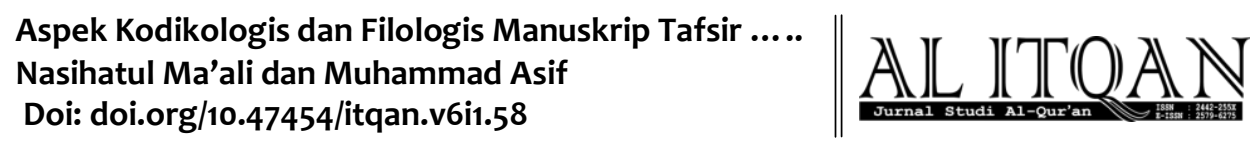

Ayat tersebut menjelaskan dialog antara Nabi Samuel dan kaumnya. Kaum Samuel tidak setuju dengan dipilihnya Talut sebagai raja. Dalam naskah kajian bentuk protes diterjemahkan dengan bahasa Jawa pada tingkatan kromo inggil. Hal tersebut terlihat dari frasa "kados pundi” yang digunakan untuk menerjemahkan lafadz قيف yang ditafsiri الوا لى yang padanan kata dalam tingkat kromo madya adalah "pripun?" dan bentuk Ngoko-nya adalah “koyo opo?”. Demikianlah unggah-ungguh dalam bahasa Jawa, di mana orang yang memiliki tingkat sosial lebih rendah menggunakan bahasa yang lebih halus ketika berdialog dengan lawan tutur yang memiliki tingkat sosial di atasnya.

Kedua, hierarki bahasa pada terjemah naskah akan teridentifikasi dalam bentuk tejemah yang berbeda-beda pada saat menyebutkan lafadz yang sama. Pemilihan diksi tersebut berdasarkan kedudukan subjek yang berkaitan. Seperti lafadz قال dalam naskah ini, memiliki tiga bentuk terjemah, yaitu ngendiko, matur dan ngucap. Hal tersebut disesuaikan dengan kedudukan subjek dari kata kerja قال Lafadz قال diterjemahkan dengan “ngendiko", yang dalam bahasa Jawa menempati tingkatan Kromo Inggil yang diperuntukan pada golongan yang memiliki kedudukan sosial tinggi sebagai bentuk penghormatan. Seperti قال maka ngendiko Allah Ta'ālā, dalam frase tersebut subjek dari lafadz قال تعالى له ${ }^{43}{ }^{43}$ adalah Allah, yang memiliki derajat tinggi sebagai Tuhan. Sehingga terjemah lafadz قال dalam konteks tersebut meggunakan bahasa Kromo Inggil.

Berikutnya قال diterjemahkan dengan "matur" yang tergolong tingkatan Kromo (Madya) dalam unggah-ungguh bahasa Jawa. Seperti pada اذ قال ابراهيم yang diterjemahkan "matur Nabi Ibrahim". 44 Posisi nabi dalam agama Islam berada di bawah kedudukan Allah Subḥānahu wa Ta'ālā. Maka terjemah yang digunakan adalah bahasa Kromo berupa matur yang di dalamnya terdapat unsur memuliakan namun tingkatannya di bawah bahasa Kromo Inggil.

Terakhir قال diterjemahkan dengan "ngucap” yang dalam bahasa Jawa berada pada tingkat Ngoko. Tingkat bahasa tersebut diperuntukkan untuk orang-orang yang memiliki derajat rendah yang posisinya di bawah tingkat bahasa Kromo dan Kromo Inggil. Seperti pada yang diterjemahkan "ngucape kafir Yahudi”." Redaksi "ngucap" dalam bahasa Jawa menempati tingkat tutur terendah, yaitu Ngoko.

\footnotetext{
${ }^{43}$ MS. Tafsir Jalālayn Pondok Pesantren Bustanul Ulum Sedan , hlm. 46.

${ }^{44}$ Ibid., hlm. 46.

${ }^{45}$ MS. Tafsir Jalālayn Pondok Pesantren Bustanul Ulum Sedan, hlm. 3.
} 


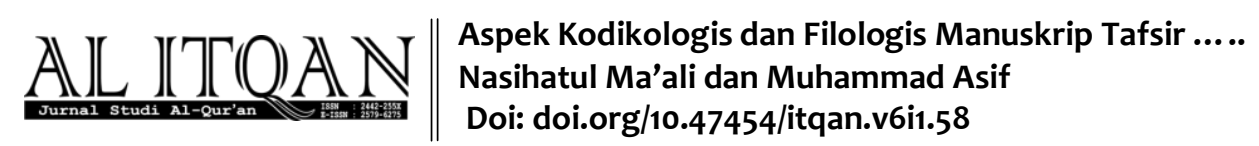

\section{Komentar dalam Naskah}

Selain penggunaan makna gandhul dan terjemah yang berhierarki, karakteristik lain dalam naskah kajian adalah memiliki catatan singkat mengenai penjelasan teks al-Qur'an dan matan tafsir. Dalam hal ini penulis menyebutnya dengan istilah syarah berdasarkan fungsinya sebagai penjelas dari teks utama (matan naskah). Diperkirakan penulis syarah dalam naskah merupakan orang yang sama dengan penulis makna gandhul. Terlihat dari goresan tinta keduanya memiliki ketebalan yang sama dan penggunaan khat sejenis menguatkan dugaan tersebut. Dalam tradis pengajian bandongan, ketika seorang santri ngasahi kitab (memberi makna gandhul) biasanya sembari mencatat penjelasan dari kiai seputar ayat yang bersangkutan. Dari situlah diperkirakan syarah dalam naskah ini lahir. Keberadaan syarah dengan tujuan untuk menjelaskan tentunya disesuaikan dengan kebutuhan dari teks yang bersangkutan. Dalam hal ini akan di paparkan posisi syarh dalam naskah Tafsir Jalālayn Pondok Pesantren Bustanul Ulum Sedan berdasarkan fungsi-fungsinya sebagai berikut:

\section{a. Penjelas Lafadz yang Masih Umum dan Sulit Dipahami}

Di sini fungsi syarah sebagai penjelas lafadz-lafadz yang masih umum atau sulit dipahami baik dari segi ayat maupun matan tafsir. Seperti syarah dalam QS. Al-Baqarah: 143

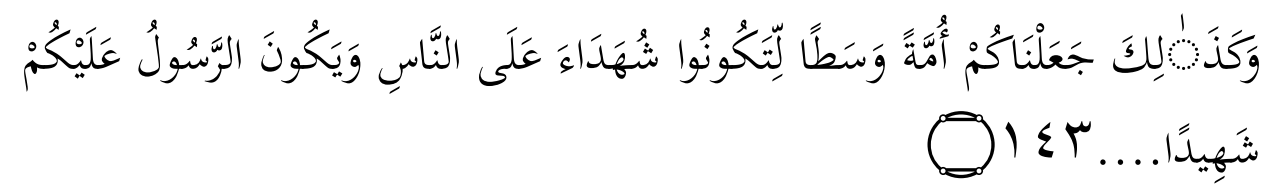

Dan demikian pula Kami telah menjadikan kamu (umat Islam), "umat pertengahan" agar kamu menjadi saksi atas (perbuatan) manusia dan agar Rasul (Muhammad) menjadi saksi atas (perbuatan) kamu. ${ }^{46}$

\begin{tabular}{|c|c|c|}
\hline Ayat al-Qur'an & Matan Tafsir Jalälayn & Syarah dalam Naskah \\
\hline كنا بالعلم والعمل & خيارا عدولاً & \\
\hline
\end{tabular}

Tabel 1 Syarah penjelas lafadz yang sulit dipahami

Pada ayat tersebut lafadz أمَنَة وَسَطَا (umat tengah) ditafsirkan dengan خيارا عدو لا (pilihan dan adil). Dijelaskan lebih mendalam lagi mengenai maksud ayat tersebut, yaitu dengan menyebut كنا بالعلم و العمل (kami berpegang teguh dengan ilmu dan amal). Umat nabi merupakan umat yang wasațan, maksudnya berpegang teguh pada ilmu dan amal yang telah diajarkan

${ }^{46}$ Al-Quddus: Al-Qur'an dan Terjemahnya, hlm.21.

16 AL-ITQAN, Volume 6, No. 1, 2020 


\section{Aspek Kodikologis dan Filologis Manuskrip Tafsir ..... Nasihatul Ma'ali dan Muhammad Asif \\ Doi: doi.org/10.47454/itqan.v6i1.58}



Nabi Sallā Allāhu 'Alayhi wa Sallam. ${ }^{47}$ Umat Nabi Muhammad Sallā Allāhu 'Alayhi wa Sallam memiliki kesempatan beramal dengan menjaga perbuatan-perbuatannya sesuai syariat yang disampaikan $\mathrm{Nabi}^{48}$ serta dapat menyeimbangkan ilmu yang diperolehnya dan mengamalkannya dengan baik. Adil dalam ilmunya artinya dapat menggunakan dengan baik kemudian diamalkan dengan baik pula ilmu tersebut. ${ }^{49}$

\section{b. Penjelas Hukum}

Posisi syarah dalam naskah selanjutnya sebagai penjelasan hukum kandungan dari ayat al-Qur'an yang tentunya tidak dijelaskan dalam matan tafsir. Sebagaimana dalam syarah QS. al-Baqarah: 228.

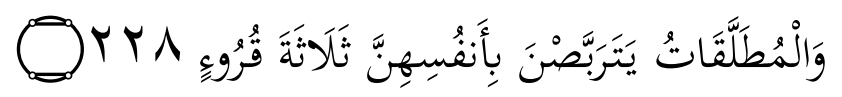

Dan para istri yang diceraikan (wajib) menahan diri(mereka) tiga kali quru'.50

\begin{tabular}{|c|c|c|}
\hline Ayat al-Qur'an & Matan Tafsir Jalālayn & Syarah pada naskah \\
\hline لَلَََّاتُ يَتَرَبَّصْنَ & 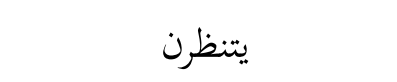 & اي وجوب التربص بانفسهن ' \\
\hline
\end{tabular}

Tabel 2 Syarah sebagai penjelas hukum

Pada awal ayat tersebut berupa وَالُُْطَلََّاتُ يَتَرَبَّْْنَ dalam matan tafsir Jalālayn dijelaksan dengan يتنظرن (menunggu). Kemudian dalam naskah tafsir Jalālayn Pondok Pesantren Bustanul Ulum Sedan disyarahi اي وجوب التربص بانفسهن (maksudnya wajib menunggu kalian semua yaitu perempuan yang ditalak), yang memberi penjelasan hukum berupa kewajiban menunggu (iddah) bagi wanita yang ditalak suaminya.

Jika dilihat dari segi bahasanya, ayat tersebut tidak menggunakan lafadz yang mengindikasikan bentuk hukum wajib. Sebagaimana keterangan Quraish Shihab bahwa redaksi ayat tersebut bukan bentuk perintah, melainkan bentuk redaksi berita. Lebih jauh ia menambahkan bahwa bentuk redaksi semacam ini merupakan gaya bahasa al-Qur'an dalam

\footnotetext{
${ }^{47}$ Muhammad al-Amīn bin 'Abdillah Armi, Tafsīr Hadāiq al-Rūḥ wa al-Rīhān fì Rawābì "Ulūm al-Qur'ān, (Beirut: Dār țauq al-Najāh, 2001), hlm. 11.

${ }^{48}$ Muhammad Rashid bin 'alī Ridhā, Tafsīr al-Manār, (Mesir: al-Hayat al-Masriyah, 1990), hlm. 5.

${ }^{49}$ Muhammad Mahmud al-Hijazi, al-Tafsī al-Wādihh, (Beirut: Dār al-Jalīl al-Jadīd, 1413 H.), hlm. 80.

${ }^{50}$ Al-Quddus: Al-Qur'an dan Terjemahnya, hlm. 35.

${ }^{51}$ MS. Tafsir Jalālayn Pondok Pesantren Bustanul Ulum Sedan, hlm. 37.
} 
memberi perintah. Redaksi tersebut dianggap lebih kuat dari pada redaksi yang menggunakan gaya bahasa perintah. ${ }^{52}$

Ketika melakukan tinjauan secara mendalam maka akan menghasilkan hukum demikian. Dalam hal ini posisi syarah dalam ayat tersebut sebagai penjelas hukum suatu lafaz yang diberitakan dalam ayat al-Qur'an. Hukum tersebut tidak dijelaskan dalam matan tafsir sehingga penulis syarah menganggap tafsir ayat tersebut perlu diberi keterangan lebih dalam.

\section{c. Menjelaskan Kembali Maksud Ayat dan Matan Tafsir}

Dalam hal ini syarah naskah tafsir Jalālayn Pondok Pesantren Bustanul Ulum Sedan tidak berkontribusi menambah penjelasan baru seputar kandungan ayat yang dijelaskan dalam matan. Syarah hanya mengulang penjelasan yang sudah dipaparkan dalam ayat dan matan tafsir. Dalam hal ini syarah terbilang catatan ringan yang memiliki fungsi sebagai penjelasan pribadi untuk mengingatkan penulisnya. Seperti catatan kembalinya dhomir (kata ganti), ${ }^{53}$ mencatat kembali apa yang ditulis dalam matan tafsir, ${ }^{54}$ Model syarah demikian yang paling banyak ditemukan dalam naskah kajian.

Berikut fungsi syarah untuk menjelaskan kembali masksud ayat sebagaimana dalam QS. al-Baqarah: 187

\begin{tabular}{|c|c|c|}
\hline Ayat al-Qur'an & Matan Tafsir Jalālayn & Syarah pada naskah \\
\hline وانتم لباس لهنّ & كناية عن تعانقتهما & اي من الرجال والنساء \\
\hline
\end{tabular}

Tabel 3 syarah sebagai penjelas kembali maksud ayat

Dalam potongan QS. al-Baqarah: 187 menjelaskan bahwa "kamu adalah pakaian baginya" kemudian dijelaskan oleh tafsir Jalālayn dengan "Sebagai kiasan mereka berdua (suami-istri) saling bergantung dan saling membutuhkan.’Pada naskahtafsir Jalālayn Pondok Pesantren Bustanul Ulum Sedan ditambahkan "yaitu para laki-laki dan para perempuan". Syarah tersebut menjelaskan dlomir (kata ganti) هما yang ada pada lafaz تعانقتهما ditujukan pada laki-laki dan perempuan (suami istri), jadi maksud dari mereka berdua adalah laki-laki dan

\footnotetext{
${ }^{52}$ M. Quraish Shihab, Tafsir al-Misbah: Pesan Kesan dan Keserasian al-Qur'an, (Jakarta: Lentera Hati, 2002), hlm. 591.

${ }^{53}$ MS. Tafsir Jalālayn Pondok Pesantren Bustanul Ulum Sedan, hlm. 27.

${ }^{54}$ Ibid., hlm. 46.

${ }^{55}$ MS. Tafsir Jalālayn Pondok Pesantren Bustanul Ulum Sedan, hlm. 27.
} 

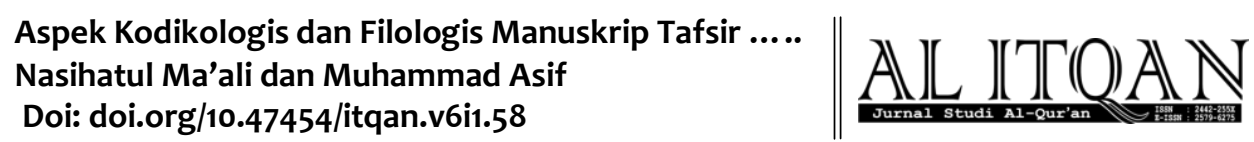

perempuan yaitu suami dan istri. Di sini fungsi syarah hanya sebagai penjelas dlomir yang ada pada matan tafsir Jalālayn.

\section{d. Mengukuhkan Dalil atau Sumber Penafsiran}

Posisi syarah sebagai penjelas sumber penafsiran dari matan tafsir Jalālayn berasal. Seorang mufassir tidak terlepas dari sumber penafsiran baik berupa dalil yang ma'thūr atau ataupun $m a$ 'qūl. Berikut contoh bentuk syarah penguraian sumber penafsiran yang ada dalam naskah:

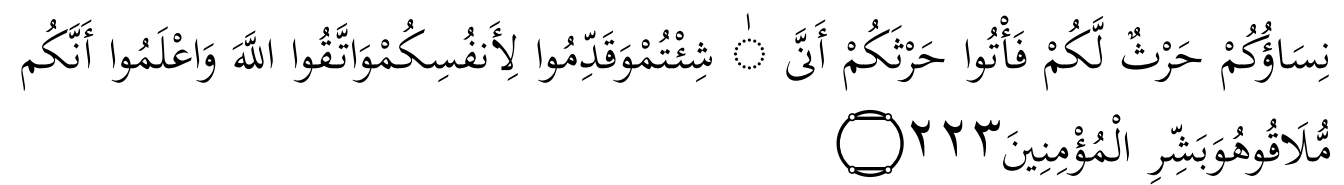

Istri-istrimu adalah ladang bagimu, maka datangilah ladangmu itu kapan saja dan dengan cara yang kamu sukai. Dan utamakanlah (yang baik) untuk dirimu. Bertakwalah kepada Allah dan ketahuilah bahwa kamu akan menemui-Nya. Dan sampaikanlah kabar gembira kepada orang yang beriman. ${ }^{56}$

\begin{tabular}{|c|c|c|}
\hline Ayat al-Qur'an & Matan Tafsir Jalālayn & Syarah pada naskah \\
\hline وَقَقَََّمُوا لَأَنْفْسِكُم & $\begin{array}{c}\text { العمل الصالح كتسمية عند } \\
\text { الجماع }\end{array}$ & 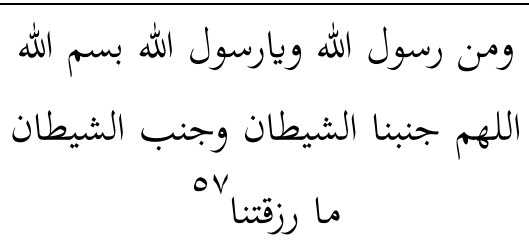 \\
\hline
\end{tabular}

Tabel 4 Syarah sebagai pengurai sumber penafsiran

QS. al-Baqarah: 223 menjelaskan mengenai hubungan suami istri. ${ }^{58}$ Pada akhir ayat disebutkan anjuran untuk melakukan amalan yang baik. Kemudian dijelaskan pada matan tafsir contoh dari amal baik dalam ayat tersebut adalah membaca basamalah ketika melakukan jima' (hubungan suami istri). Dalam syarah kemudian dijelaskan dalil berupa hadis yang menjadi dasar amalan tersebut, meski tanpa menyebut sumber.

Hadis yang disebutkan merupakan hadis berkualitas șahih yang diriwayatkan oleh Bukhari dan Muslim dalam kitab shahihnya. ${ }^{59}$ Hal tersebut menunjukkan posisi syarah dalam

\footnotetext{
${ }^{56}$ Al-Quddus: Al-Qur'an dan Terjemahnya, hlm. 34.

${ }^{57}$ MS. Tafsir Jalālayn Pondok Pesantren Bustanul Ulum Sedan, hlm. 37.

${ }^{58}$ M. Quraish Shihab, Tafsir al-Misbah: Pesan Kesan dan Keserasian al-Qur'an, hlm. 584.

${ }^{59}$ lihat Sahīh Bukhārī dan Muslim.
} 
ayat sebagai pengukuhan dalil dalam matan tafsir untuk memperkuat penjelasan yang ada pada tafsir dengan cara menghadirkan dalil mengenainya.

Dari ketiga karakteristik yang dipaparkan di atas menunjukkan bahwa kajian tafsir pada masa 1840 M. telah dipelajari bahkan terlihat sudah mendalam. Dari terjemahnya yang sudah melibatkan analisis gramatika hingga pembahasan yang mendalam pada syarah mengenai hukum, penjelasan lafaz yang mujmal serta kaitannya al-Qur'an dengan ilmu lain. Data tersebut mengindikasikan di daerah Rembang pada pertengahan abad ke-19 (1840 M.) pembelajaran tafsir al-Qur'an sudah mulai berkembang. Al-Quran bukan hanya sekedar dibaca namun juga sudah dipahami makna dan maksud yang termuat di dalamnya.

\section{Kesimpulan}

Berdasarkan deskripsi dan analisis data penelitian di atas penulis pada simpulan bahwa naskah objek kajian merupakan salinan tafsir Jalālayn karya Jalaluddin al-Mahalli dan al-Suyuti. Naskah tersebut yang disalin dan diberi catatan berupa komentar sekitar tahun 1840 M. Dan berdasarkan analisis logat bahasa yang disebutkan sebelumnya dapat disimpulkan naskah berasal dari daerah tempat ditemukannya, yaitu wilayah Rembang. Secara fisiknaskah tafsir Jalālayn tersebut dilengkapi dengan hal-hal layaknya naskah mushaf al-Quran pada umumnya seperti iluminasi, batas-batas surah dan ruku' yang jarang ditemukan pada naskah salinan Tafsir Jalālayn.

Dalam naskah kajian ditemukan teks-teks di luar ayat al-Qura'an dan matan tafsir yang menjadi karakteristik teks yang mungkin membedakan naskah Tafsir Jalālayn objek kajian dengan naskah Tafsir Jalālaynlainnya. Terdapat tiga bentuk karakteristik yang mengarah pada media pemahaman terhadap teks al-Qur'an beserta tafsirnya (baca: Jalālayn). Pertama, penggunaan Makna Gandhul yang berbahasa Jawa menjembatani pembaca yang notabenenya orang Jawa untuk memahami teks yang berbahasa Arab. Uniknya Makna Gandhul yang ada pada teks juga telah memuat kode-kode analisis gramatika bahasa Arab dalam bentuk yang sudah cukup mapan. Kaberadaan kode-kode gramatika tersebut dianggap cukup dini hadir pada naskah berumur dua abad silam. Kedua, hierarki bahasa dalam terjemah memberi pemahaman bagi pembaca naskah karena mereka orang Jawa terbiasa dengan tradisi unggah-ungguh bahasa untuk membedakan posisi seseorang berdasarkan kedudukan derajatnya. Ketiga, catatan singkat yang disebut dengan syarah yang berada di luar teks utama sebagai penjelas ayat-ayat al-Qur'an dan tafsirnya disajikan mengunakan bahasa Arab. Syarah 
Aspek Kodikologis dan Filologis Manuskrip Tafsir .....
Nasihatul Ma'ali dan Muhammad Asif
Doi: doi.org/10.47454/itqan.v6i1.58

tersebut memberi pemahaman dan pengetahuan yang lebih mendalam terhadap pemahaman tafsir Jalālayn yang ijmāli (global). Syarah berisi catatan penjelas al-Qur'an dan tafsirnya yang merujuk pada dalil, atau penafsiran mufassir terdahulu, sehingga memberi pemahaman mendalam terhadap ayat al-Qur'an baik dari segi hukum, lafadz yang sulit dipahami maupun rujukan-rujukan yang tidak termuat dalam matan Tafsir Jalälayn. Dari ketiga karakteristik tersebut membuktikan bahwa pada pertengahan abad ke-19 (1840 M.) di daerah Rembang pengajian kitab tafsir telah berkembang, meskipun masih menggunakan matan tafsir Jalālayn sebagai sumber primernya. 


\section{DAFTAR PUSTAKA}

Al-Quddus: Al-Qur'an dan Terjemahnya. Kudus: CV. Mubarokatan Thoyyobah. tth.

Amin, Faizal. "Prevesi Naskah Klasik". Jurnal Katulistiwa, vol. 1, no. 1, (2011). (https://doi.org/10.24260/khatulistiwa.v1i1.184).

Armi, Muhammad al-amīn bin 'Abdillah. Tafsīr Hadāiq al-Rūḥ wa al-Rīhận fì Rawābì "Ulūm al-Qur'ān. Beirut: Dār țauq al-Najāh. 2001.

Asif, Muhammad. "Tafsir dan Tradisi Pesantren: Karakteristik Tafsir al-Ibīz Karya Bisri Mustofa", Șuhuf Jurnal Pengkajian al-Qur'an dan Budaya, vol. 9, no. 2, (2016).(https://doi.org/10.22548/shf.v9i2.154)

Berg, L.W.C. Van den. "Het Mohammedaansche Godsdienstonderwijs of Java en Madoera en Daarbij Gebruikte Arabische Boeken", Tijdschrift Voor Indische Taal-Land-En Volkenkunde Uitgegeven Door Het Bataviaasch Genootschap van Kunsten en Wetenschappen, vol. 31, 1886.

Bruinessen, Martin van. Kitab Kuning Pesantren dan Tarekat. Bandung: Mizan. 1995.

Chijs, J. A. Van der. "Bijdragen Tot de Geschiedenis van Het Inlandsch Onderwijs in Nederlandsch-Indië”. Tijdschrift Voor Indische Taal-land-en Volkenkunde Uitgegeven door Het Bataviaasch Genootschap van Kunsten en Wetenschappen. vol. 14, no 5. 1864.

Churchill, W.A. Watermarks in Paper In Holland, Englad, France etc: In The XVII Centuries and Their Interconnection. Amsterdam: Menno Hertzberger \& Co, 1965.

Dhofier, Zamakhsyari. Tradisi Pesantren: Studi Pandangan Hidup Kyai dan Visinya Mengenai Masa Depan Indonesia. Jakarta: LP3ES. 1982.

Fakhriati. "The Use of Paper in the Acehnese Islamic Manuscripts and Its Historical Context", Hiritage of Nusantara International Journal of Religious Literature Heritage, vol.2, no. 1, (2013).

Fathurahman, Oman. Filologi Indonesia: Teori dan Metode. Jakarta: Prenadamedia Group. 2015. 
Hijazi (al), Muhammad Mahmud al-Tafsī al-Wādihh. Beirut: Dār al-Jalīl al-Jadīd, 1413 H.

Lubis, Nabilah. Naskah, Teks dan Metode Penelitian Filologi. Jakarta: Yayasan Media Alo Indonesia, 2007.

Mahalli (al), Jalaluddin dan Jalaluddin al-Suyuti. Tafsir Jalalain, terj. Bahrun Abu Bakar dkk, Bandung: Sinar Baru Algensindo, 2019.

Masrukhi. "Penerjemahan Arab-Jawa Tradisi Pesantren Pada Karya Kitab-Kitab Klasik: Analisis Fungsi”, Sasdaya Gadjah Mada Journal of Humanities, vol. 2, no. 1, (2017).(https://doi.org/10.22146/sasdayajournal.31744)

MS Tafsir Jalālayn Pondok Pesantren Bustanul Ulum Sedan, P.P Bustanul Ulum Sedan.

Muhsin, Imam. Al-Qur'an dan Budaya dalam Tafsir al-Huda Karya Bakri Syahid. Yogyakarta: eLSAQ. 2013.

Mulyadi, Sri Wulan Rujiati. Kodikologi Melayu di Indonesia. Depok: Lembar Sastra Edisi Khusus No.21 Fakultas Sastra Universitas Indonesia, 1994.

Pudjiastuti, Titik. "Tulisan Pegon Wujud Identitas Islam-Jawa: Tinjauan atas Bentuk dan Fungsinya", ȘuhufJurnal Pengkajian al-Qur'an dan Budaya, vol. 2, no. 2, (2009).(https://doi.org/10.22548/shf.v2i2.92).

Ridhā, Muhammad Rashid bin 'Alī. Tafsīr al-Manār. Mesir: al-Hayat al-Masriyah, 1990.

Rohmana, Jajang. "Empat Manuskrip Al-Qur'an di Subang Jawa Barat”, Wawasan: Jurnal Ilmiah Agama dan Sosial Budaya, vol. 3, no. 1, (2018). (https://doi.org/10.15575/jw.v3i1.1964).

Shihab, M. Quraish Tafsir al-Misbah: Pesan Kesan dan Keserasian al-Qur'an, Jakarta: Lentera Hati, 2002.

Soedjarwo dkk. Geografi Dialek Bahasa Jawa Kabupaten Rembang. Jakarta: Pusat Pembinaan dan Pengembangan Bahasa Departemen Pendidikan dan Kebudayaan, 1987. 
Steenbrink, Karel A. Beberapa Aspek Tentang Islam di Indonesia Abad ke-19. tnp: Bulan Bintang, 1980.

Sudaryanto, “Tiga Fase Perkembangan Bahasa Indonesia 1928-2019”, Jurnal Pendidikan dan Sastra Indonesia, vol. 2, no. 1, (2018). (https://doi.org/10.21009/AKSIS.020101).

Wahidi, Ridhoul. "Hierarki Bahasa dalam Tafsir Al-Ibrīz li Ma'rifah Tafsīr al-Qur'an al- 'Azīz Karya KH. Bisri Musthofa", ȘuḥufJurnal Pengkajian al-Qur'an dan Budaya, vol. 8, no. 1, (2015). (https://doi.org/10.22548/shf.v8i1.18).

Wawancara dengan Kiai Sirojjudin Azizi, Sedan, Rembang, 27 Februari 2020. 